\title{
Expressions of futurity in the Vilamovicean language ${ }^{1}$
}

\author{
Alexander Andrason \\ Department of Ancient Studies, Stellenbosch University, Private Bag X1, 7602 Matieland, South Africa* \\ E-mail: aleksand@hi.is
}

\begin{abstract}
The present paper aims at presenting all major morphosyntactic means of expressing future meaning in Vilamovicean, the smallest Germanic language spoken in the town of Wilamowice in Southern Poland. As will be demonstrated - and contrary to the opinion found in the literature published so far the concept of futurity is not limited to the wada future but, rather, can be conveyed by a number of constructions. These forms may be divided into two main groups: the first one includes formations that are employed with no restriction by all speakers (among others these are constructions like the present tense, the periphrases wada + infinitive, wjyd + past participle or adverbials, wada hon/zajn + past participle, and zuta + infinitive, as well as various modally based future expressions) while the second class consists of two novel and "rare" locutions which are accepted uniquely by a limited number of speakers (this group includes locutions such as wada + past participle and wada + present). Furthermore, two other Vilamovicean periphrases will be discussed, namely wie + past participle and wie + present, which, even though restricted to the conditional value, display a similar morphosyntactic shape as the "rare futures".
\end{abstract}

Keywords: Germanic family, Vilamovicean language, verbal system, future

\section{Introduction}

Vilamovicean (Wymysöeryś [vł̇ṁ̇øłrI6]) is a Germanic language spoken in the town of Wilamowice situated in Western Galicia on the boundary with Silesia ${ }^{2}$, in the southern part of Poland. Like Silesian and its vernaculars, it is a Central East German dialect which derives form Middle High German. Currently, Vilamovicean can be defined as the smallest Germanic language in the world: it is understood by roughly eighty persons, but actively used by no more than twenty fully competent speakers. Since the language is employed by a highly reduced number of native speakers among which almost all are more than 80 years old, its future is in real danger.

It should be noted that Vilamovicean, despite having a significantly weaker demographic and political status than the dominant Polish language, has preserved its authentic Germanic character: it has not suffered any significant Slavic influence ${ }^{3}$ and, even if exposed to the unceasing language contact environment, it is by no means a creole or mixed language. 
In descriptions of the Vilamovicean verbal system published so far, one finds very little dedicated to the future tense and the expressions of the futurity. According to short Vilamovicean grammar books from the beginning of the twentieth century (Kleczkowski 1920; Młynek 1907), and as maintained later in a few superficial descriptions of the verbal system (Lasatowicz 1992; Wicherkiewicz 2004), future events and situations are indicated by means of an analytic construction that resembles the German future tense with the auxiliary werden: wada + infinitive I (wada kuma 'will come') and wada + infinitive II (wada zajn gykuma 'will have come' or wada hon gykoüft 'will have bought'). No other means of conveying the future meaning are identified in the existing and extremely scarce literature. However, in light of the evidence collected by the author and Tymoteusz Król during their field work in 2008 and 2009, there is no doubt that the expression of future actions is not limited to the wada construction. On the contrary, the futurity may be conveyed by a number of formations, of which some can be found in other Germanic languages while others are particular to Vilamovicean. The present paper aims at enumerating all such major morphosyntactic means of expressing the future meaning in Modern Vilamovicean ${ }^{4}$. The constructions involved in expressing future meaning may be divided into two main groups. The first group includes formations that are used without restrictions by all speakers, while the second group consists of two "rare" locutions which are employed uniquely by a limited number of speakers. These two groups will be discussed in more detail in Section 2. Furthermore, two other Vilamovicean formations will be presented, namely wie + past participle (active meaning) and wie + present participle, which, even though restricted to the conditional value, display a similar morpho-syntactic structure to the "rare futures" mentioned above.

It must be emphasized that, since this is a purely synchronic study which is limited to the description of the present situation of the Vilamovicean language, the question of the foundation of the innovative futures - in itself highly interesting - does not constitute our scientific objective.

The following 19 persons, considered to have the best proficiency in Vilamovicean, were selected as informers in the current study on expressions of futurity: Kazimierz Grygierczyk (born 1913), Anna Danek (1916), Anna Schneider (1920), Elżbieta Młynarska "Milerka" (born 1921), Helena Biba "Płacznik" (1922), Anna Zejma "Luft" (1923), Elzbieta Babiuch (1923), Elżbieta Matysiak "Hala-Mockii" (1924), Helena Gasidło (1924), Waleria Brzezina "Cepok" (1925), Rozalia Hanusz "Linkuś" (1926), Stanisław Fox "Luft" (1926), Anna Fox "Luft" (1927), Helena Rozner "Biba" (1928), Helena Nowak (1928), Inga Danek (1928), Józef Gara (1929), Elżbieta Gandor (1930) and Emilia Danek (1933). Since, aside from several poems composed by Florian Biesik at the beginning of the twentieth century (and some other scarce texts), there is no Vilamovicean literature ${ }^{5}$, the field work conducted by the author seems to be the only reliable source of the contemporary state of the language.

\section{Types of expressions used to indicate futurity in Vilamovicean}

As mentioned in Section 1, the expressions used to indicate future events and situations in modern Vilamovicean can be divided into two main groups. One group consists of forms that are employed by all the Vilamovicean speakers, and also have frequent homologues found in several other Germanic languages. The second group entails constructions that are used 
uniquely by some, but not all, Vilomoviceans, of which one is the youngest active and fluent speaker (born 1933). These constructions will now be discussed separately in more detail.

\subsection{Regular constructions}

As in other Germanic languages, future events and situations are commonly conveyed by the present tense, which of course, mainly serves to indicate present activities, both actual and general, as illustrated by sentences (1a-c). In that case, one expects to find an adverb (adverbial phrase) or some lexical and contextual elements that point explicitly to the future temporal reference, as in sentences (1a) and (1b). In some instances, the present tense may also be employed to express prospective actions that precede other future activities, thus corresponding to the category of the future perfect. This is illustrated by sentence (1c).
a. Yhy hjy uf cy taza dy gazyt y ar wajt.
I hold off to read the newspaper in a while
"I will stop reading the newspaper in a while."
b. Piöer tog fï̈en dy kyndyn wag.
some days go the children away
"In a few days, the children will leave."
c. Dü wyst ny roüzgejn wen dy ny ufroümst dy goncy hyt.
you will not leave before you not clean the whole house
"You will not leave before you have cleaned the whole house."

The unambiguous way of indicating future actions consists of employing the periphrasis wada (har wyt) 'will' ('he will') + infinitive that corresponds to the German construction werden + infinitive. This is illustrated by sentences (2a-c).
a. S'öwyts wysty zon ${ }^{8}$ ufa film.
the evening will-you-SG watch on-the movie
"In the evening, you will watch the movie."
b. Mün woh krigia a pokto.
tomorrow will-I receive a packet
"Tomorrow, I will receive a packet."
c. Ym cwelf wyt dy züp gykoht zajn.
in-the twelve will the soup cooked be
"At 12, the soup will be cooked."

The wada future may also be employed in a sequence representing reported speech, after an introductory past tense verb (either in the Preterite or in the Perfect), in order to express prospective events corresponding to the future past category. This is illustrated by the examples in (3) below:

a. A höt gyziöet do'a wyt dos moha.

he has said that he will this do

"He said that he would do it." 
b. A kuzt do'a wyt kiöefa s'brut.

he said that he will buy the-bread

"He said that he would buy the bread."

When the verb wada is in the present tense and not used as an auxiliary introducing another verb, it denotes future events. In such cases the verb wada co-occurs with a past participle (rendering a passive meaning), a noun, an adjective, or a prepositional phrase, and renders the meaning 'will be / will become'. This is illustrated by the examples in (4). It should be noted that the third person singular form of the verb wada in these examples is systematically wjyd, instead of the form wyt encountered in the examples in (3) where wada functions as the future auxiliary. In this regard, wada behaves like the Icelandic verb verða 'become / will be': for example, the Vilamovicean sentence Haor wjyd ym hoüs 'He will be at home' is equivalent to the Icelandic Hann verður heima 'He will be at home'. ${ }^{9}$ Furthermore, in sentences such as (4a) and (4b) where the wjyd + past participle construction appears, only the participles derived from transitive verbs may be employed. This means that there are no examples of phrases such as *haor wjyd gykuma 'he will come'.

a. $\quad$ Fir draj jür wjyd dy śtrös gyboüt (= wyt dy śtrös zajn gyboüt $\left.{ }^{10}\right)$. for three year will / becomes the street built

"The street will be built in three years."

b. Mün wjyd dy hyt gymött a gonca tog (= wyt dos hoüz zajn gymött). tomorrow will / becomes the wall painted a whole day "Tomorrow, the wall will be painted the whole day."

The lexical verb wada with the meaning 'become' may, like any other main verb, form the regular future periphrasis with the auxiliary wada. This can be seen in the examples in (5):

a. Zy kuza do dy kjyh wyt wada gyryht (= wjyd gyryht $\left.{ }^{11}\right)$. they say that the church will become restored "They say that the church will be restored."

b. Wymysiöejer śpröh wyt nymer ny wada fergasa (= wjyd nymer ny fergasa). Vilamovicean language will never not become forgotten "The Vilamovicean language will never be forgotten."

As in German, future anterior or future perfect events are expressed in Vilamovicean by means of the periphrasis wada hon / zajn + past participle (the German counterparts being werden gekauft haben 'will have bought' / werden gekommen sein 'will have ${ }^{12}$ come'). This periphrasis is shown in examples (6a-d):

(6) a. Y ar wajt wo yhy hon dy kyh ufgyroümt. in a while will I have the kitchen cleaned "I will have cleaned the kitchen in a while." 
b. Mün maj nökwer wyt hon gykoüft a oüta. tomorrow my neighbour will have bought a car "Tomorrow, my neighbour will have bought a car."

c. Wen yh s'mytagasa wo'h hon koht, woh abysta rün. when I the-lunch will-I have cooked, will-I a-little rest "When I have cooked the lunch, I will rest a little."

d. Wen haor wyt zajn gykuma, woh jum hylfa. when he will be come, will-I him help "When he has come, I will help him."

However, it should be noted that the simple wada future may also introduce future events that precede other prospective actions. In other words, it can function as a future perfect as illustrated by the examples in (7) (cf. also (1c) for an example of the present tense in this function):

a. Wen wyt kuma der nökwer, to wo'h um ziöen dy byst ny. when will come the neighbor, then will-I him say you are not "When the neighbor comes, I will tell him that you are not here."

b. Dü wyst ny gejn śtöfa, wat dy dos ny wyst enda. you will not go sleep, before you this not will finish "You will not go to sleep, before you have finished this."

The future tense can also be formed with the auxiliary verb zuta 'shall', followed by the infinitive of the lexical verb. This formation, illustrated by the examples in (8), corresponds to the Dutch expression $i k z a l$ 'I shall' + infinitive and has a stronger modal (optative, volitional and generally epistemic) nuance than the constructions with wada.

a. Wo jum ziöen do'a mih zo byzihia.

I-will him say that he me shall visit

"I will tell him that he shall visit me."

b. Yhy wo byta dy nökweryn do zy zo mer hylfa.

I will ask the neighbor that she shall me help

"I will ask the neighbor to help me."

As is the case with wada, the auxiliary zuta in the present tense may express future events introduced from an explicit past perspective. Sentences (9a) and (9b) illustrate this:

(9) a. Der dökter ziöet do yh zo rün.

the doctor said that I shall rest

"The doctor said that I should rest."

b. Yh ho gybata dy tohter do zy mir zo oüzwośa.

I have asked the daughter that she me shall help

"I have asked (or I asked) my daughter to help me." 
The modal tone, which almost always accompanies the zuła future, is especially clear in the following examples in (10) where the formation expresses the idea of soft obligation:

a. Zy zon (zuta) kiöefa orputn.

they shall buy potatoes

"They shall / should let them buy potatoes."

b. A zo najkuma.

he shall come-in

"May he come in / let him come in!"

Finally, there are several modal verbs that may indicate future events and are always accompanied by a clear modal tone, namely müssa 'must', kynna 'can', wytta 'want to', diyfa 'need to, ought to, should' and mygja 'may' + infinitive. Some examples of the use of these modal verbs are given in (11):

(11) a. Yh mü fietik moha s'öwytasa.

I must ready make the dinner

"I will have to prepare the dinner."

b. Konsty kuma mün?

can-you come tomorrow

"Can you come tomorrow?"

c. Mün djef krigia a pokło.

tomorrow shall-I receive a packet

"Tomorrow I should receive a packet."

d. S'kon zajn myht hor mih tiwa.

it-can be might he me love

"It can be that maybe he will love me / maybe he will fall in love with me."

In all such cases, one may also employ the explicit future tense with the auxiliary wada. The only difference between the examples in (11) and those in (12) lies in the fact that the latter ones indicate the futurity in an explicit way, while the former also allow for the present (both actual and general) interpretation.

(12) a. Yh wo müsa fietik moha s'öwytasa.

I will must ready make the dinner

"I will have to prepare the dinner."

b. Wysty kyna mün kuma?

can-you can tomorrow come

"Can you come tomorrow? / Will you be able to come tomorrow?" 
c. Mün wo diyfa krigia a pokto. tomorrow I-will shall receive a packet

"Tomorrow, I shall receive a packet."

d. S'kon zajn wyt hor mygia mih tiwa.

it-can be will he may me love

"It can be that / maybe he will love me."

Finally, it should be observed that the periphrasis with the verb müssa 'must' is sometimes partially "de-modalized" and denotes simple future actions introduced by verbs of asking and telling to do something. In that case, the periphrasis functionally approximates the syntactically motivated subjunctive modality (Bybee, Perkins and Pagliuca 1994). This is illustrated by sentences (13a) and (13b):
a. $\quad$ Der dökter ziöet do'h mü rün.
the doctor told that he must rest
"The doctor told him to rest."

b. Yh ho gybata dy tohter do zy mir mü oüzwośa.

I have asked the daughter that she me must wash

"I have asked my daughter to do the laundry."

\subsection{Rare constructions}

In addition to the regular constructions discussed in Section 2.1, which are acceptable for all Vilamovicean speakers and for which equivalents may easily be found in numerous Germanic languages, the Vilamovicean language has also developed two alternative ways of conveying the future meaning. The first one of these alternative ways of expressing future meaning, corresponds to a periphrasis that consists of the auxiliary wada (third person singular wyt) and the past participle. This construction, contrary to the wjyd future illustrated by examples (4a) and (4b), conveys an active meaning and may be employed with intransitive verbs (see also example (16a) below). An example of such a construction is given in (14).

(14) Yhy wo gybata dy nökweryn (Emilia Danek, born 1933).

I will asked the neighbour

"I will ask the neighbour."

(usually: wo bata 'will ask' / wo hon gybata 'will have asked')

The second alternative way of conveying the future meaning consists of a novel periphrasis in which the verb wada is used as a simple future particle and is placed before the main verb, which is inflected for the present tense. This construction is illustrated by (15):

(15) Der nökwer höt mih gyfret op wo ferkiöef s'fald (Emilia Danek, born 1933).

the neighbour has me asked if I-will I-sell the field

"The neighbor has asked me if I will sell him the field."

(usually: yhy wa ferkiöefa 'I will sell'/ yhy ferkiöef 'I sell')

These two rare constructions have conditional homologues where the auxiliary wada in the past subjunctive tense wie 'would', substitutes the future with wyt. Consequently, the 
periphrasis wie + past participle provides the conditional active meaning shown in sentence (16a). In addition, the item wie may precede the main verb in the present tense, also imposing the conditional reading, as illustrated by $(16 \mathrm{~b})$ :

a. Wen dy mer dos hetst gyziöet gestyn, wie'h ju mytum gykuzt (Waleria Brzezina, born 1925).

if you me this had told yesterday, would-I just with-him talked

"If you had told me that yesterday, I would already have talked to him." (usually: wie kuza 'would talk'/ het gykuzt 'would have talked')

b. Wen dy mer hetst gyhulfa cyjür, to wie'h oü der hylf (Helena Gasidło, born 1924).

if you me had helped last-year, then would-I too you help-I

"If you had helped me last year, I would help you too."

(usually: wie hylfa 'would help' / het gyhylft 'would have help')

It should be noted that, among all nineteen fluent Vilamovicean speakers, only four employed the "rare" formations presented above. The rest of the informants perceived such "innovative forms" as not entirely correct ${ }^{13}$.

The various regular and rare constructions discussed in Sections 2.1 and 2.2 are summarised in Table 1 below.

Table 1. Vilamovicean expressions of futurity

\begin{tabular}{|c|c|}
\hline \multirow{7}{*}{ Regular } & present tense \\
\hline & wada (3SG $w y t)+$ infinitive \\
\hline & wada (3SG wjyd) + past participle (passive meaning) / adverbial \\
\hline & wada hon / zajn + past participle \\
\hline & zuta + participle \\
\hline & müssa, kynna, wytta, diyfa, and mygja + infinitive \\
\hline & demodalized müssa + infinitive \\
\hline \multirow[t]{2}{*}{ Rare } & wada (3SG $w y t)+$ past participle (active meaning) \\
\hline & wada (3SG wyt) + present tense \\
\hline
\end{tabular}

\section{Conclusion}

In light of the evidence presented in this paper, we may conclude that the concept of futurity in the Vilamovicean language is by no means limited to the wada future but, on the contrary, can be conveyed by a number of constructions. All these futures may be divided into two main groups, summarised in Table 1. The first group consists of expressions which are accepted by all the informers: these include constructions like the present tense, the periphrases wada + infinitive, wjyd + past participle or adverbial, wada hon/zajn + past participle, and zuła + infinitive, as well as other clearly modally-based future expressions, e.g. müssa, kynna, wytta, diyfa, and mygia + infinitive (cf. Section 2.1). These locutions also correspond to typical Germanic future grams. The second group consists of two expressions: $w a d a+$ past participle (active meaning) and wada + present (cf. Section 2.2). These periphrastic futures are particular to a limited group of speakers and are thus significantly less frequent than the regular constructions. 
* Alexander Andrason is also affiliated with the Department of Hebrew and Aramaic Studies at the Complutense University in Madrid.

\section{Notes}

1. Portions of the evidence provided in this paper were previously presented at a conference at the School of Oriental and African Studies (University of London) in the seminar series Language Support and Revitalisation, Endangered Languages on 20 October 2009.

2. According to the administrative division Wilamowice constitutes a part of Województwo Śląskie (Silesian Province).

3. In most cases, the Polish influence is reduced to lexical and phraseological borrowings.

4. The analysis and description of the Vilamovicean verbal system presented here form part of a wider research project led by the author in collaboration with Tymoteusz Król, that aims at writing a compendious grammar of Vilamovicean. A description of the functional properties of the Preterite and Perfect was presented by Alexander Andrason at a conference at Cambridge University in 2008 (cf. Andrason 2008b) and recently published under the title "Vilamovicean verbal system - Do the Preterite and the Perfect mean the same?" (cf. Andrason 2010).

5. For a review of all written records of the Vilamovicean language see Wicherkiewicz (2004). Additionally, it should be noted that some songs were recently published by Danek (2007), Gara (2006) and Dobczyński (2002).

6. The relevant Vilamovicean forms that convey the future meaning will be given in bold type.

7. The author follows the Vilamovicean spelling convention which has been proposed by Tymoteusz Król and which he has himself already employed both in the work on the Vilamovicean Grammar and in all published articles (cf. Andrason 2008a, 2008b, 2009 and 2010).

8. In each case, the first bold-face element is a different form of the verb wada. The second element in bold case indicates the infinitive of the main verb.

9. This means that the present tense of Vilamovicean wada and Icelandic verða, in cases where the two predicates are used as lexical main verbs with the meaning 'become', consistently has a future reading, i.e. 'will become'. Compare the Vilamovicean sentence Haor wjyd mid 'He will be tired' with an analogous Icelandic expression Hann verður preyttur.

10. The sentences in brackets show an alternative manner of expressing future events which consists of employing the already discussed periphrasis wada + infinitive. In these cases, the expression wyt zajn signifies 'he will be'.

11. The sentence in brackets refers to the previously explained manner of expressing future events (illustrated by examples (4a) and (4b)) where the third person singular form of the verb wada appears as wjyd. In the present cases, the expression wjyd gyryht literally signifies 'he will be (he will become) restored'.

12. The expressions literally means 'will be come'.

13. In the case of Vilamovicean, it is hardly appropriate to speak about "correctness". It must be emphasized that there is no such thing as a standard variety of Vilamovicean. The language, even though limited to a small area and a small population, surprisingly includes some dialectal variations - this is especially evident in the lexicon. 
Consequently, people do not classify a given form as "incorrect" but rather propose an alternative, i.e., what they would say.

\section{References}

Andrason, A. 2008a. Vilamovicean and the language contact phenomenon - the influence of Polish on the smallest Germanic language. Talk presented at the Institute of Linguistics, University of Manchester, 6 May 2008.

Andrason, A. 2008b. Do the Preterit and the Perfect mean the same? Some remarks on the Vilamovicean verbal system from the grammaticalization perspective. Talk presented at the Indo-European Seminar Series at the Department of Classics, University of Cambridge, 3 December 2008.

Andrason, A. 2009. Expressions of futurity in the Vilamovicean language. Talk presented at the School of Oriental and African Studies SOAS, University of London. 21 October, 2009.

Andrason, A. 2010. Vilamovicean verbal system - Do the Preterite and the Perfect mean the same? Linguistica Copernica. Toruń: Wydawnictwo Universytetu im. Mikołaja Kopernika w Toruniu. pp. 371-285.

Bybee, J, R. Perkins, and W. Pagliuca. 1994. The Evolution of Grammar. Chicago and London: The University of Chicago Press.

Danek, J. 2007. Wymysöjer śtytta. Wilamowice: Miejsko-Gminny Ośrodek Kultury.

Dobczyński, W. 2002. Śpiewnik Gminy Wilamowice. Wilamowice: Gmina Wilamowice.

Gara, J. 2006. Zbiór piosenek wilamowskich. Wilamowice: Gmina Wilamowice.

Kleczkowski, A. 1920. Dialekt Wilamowic w zachodniej Galicji. Fonetyka i fleksja. Kraków: PAN.

Lasatowicz, M. 1992. Die deutsche Mundart von Wilamowice zwischen 1920 und 1987. Opole: Wyższa Szkoła Pedagogiczna.

Młynek, L. 1907. Narzecze wilamowickie. Tarnów: J. Pisz.

Wicherkiewicz, T. 2004. The Making of a Language. Trends in Linguistics. Documentation 19. Berlin and New York: Mouton de Gruyter. 